\title{
Focando na escuta: som, música e comunicação
}

Apresentamos nessa edição o dossiê Música e Som, atendendo

a uma demanda crescente em nossa área. Nos últimos anos, temos observado um aumento significativo de pesquisas sobre música popular nos programas de pós-graduação em Comunicação em todo o país. Consolidada internacionalmente como uma área de pesquisa interdisciplinar e com um histórico de mais de três décadas, a música popular tem sido assunto em diversas disciplinas no Brasil, com destaque para a História, Letras, Sociologia e, mais recentemente, Música e Comunicação.

Tal fenômeno se coaduna com um momento específico da reflexão sobre práticas culturais midiatizadas, que parece cada vez mais acionar interpretações sobre 0 "som" de uma maneira geral e a "música" de modo mais específico. No âmbito dos estudos mundiais de cinema e audiovisual, os/as pesquisadores/as dedicam espaço crescente a considerações e debates sobre a "banda sonora", que envolve não somente a música propriamente dita, mas também todo 0 universo que circunda o trabalho de sound design, atividade profissional requisitada e valorizada nas grandes e médias produções.

Numa época de transições e incertezas, as audibilidades que atravessam a circulação de artefatos culturais por meio 
de diversos suportes e tecnologias norteiam modos de ser e estar, de compartilhar, de sociabilizar-se. Várias pesquisas atuais apontam para as tecnologias da escuta como vetores fundamentais de estabelecimento desse processo.

0 artigo de abertura deste dossiê, intitulado Media Revolution on 14th Street: Immigration, Vaudeville and the Nascence of Electronic Media in New York City at the Turn of the 20th Century, assinado pelo pesquisador norte-americano Robert Albrecht, analisa a fundação da indústria do entretenimento a partir do vaudeville na virada do século XIX para o XX, em Nova York. Segundo o autor, o vaudeville criou uma síntese cultural que seria a matriz para o desenvolvimento de novos artefatos tecnológicos da indústria do entretenimento no início do século XX, como a música popular, o rádio e o cinema.

Saltando mais de cem anos e para o outro lado do Atlântico, os pesquisadores Luis Alfonso Albornoz e Juan Ignacio Gallego discutem no texto La industria de la música popular en España: los sellos independientes en la era digital as estratégias desenvolvidas pelas gravadoras e distribuidoras independentes espanholas para ampliar seu mercado, com destaque para análises sobre sua presença nas redes e serviços digitais.

Com o sugestivo título Nova Orleans não é aqui?, Cíntia Fernandes e Micael Herschmann discutem a consolidação de uma cena do jazz no Rio de Janeiro a partir da atuação do grupo Nova Lapa Jazz. No trabalho, desenvolvem a ideia de uma "musicabilidade" baseada na ocupação das ruas com música, fenômeno de grande recorrência na cidade. A sonoridade urbana também é o tema do artigo assinado por Fernando Morais da Costa, que analisa produções cinematográficas em dois momentos históricos: 0 contemporâneo e a passagem do cinema mudo para o filme sonoro. Intitulado Sons 
urbanos e suas escutas através do cinema, 0 artigo discute de que maneira as escutas dos filmes podem provocar no/a espectador/a uma reflexão sobre 0 sua relação com os sons que o/a circundam no cotidiano urbano.

Sobre a possibilidade de escutar o Outro: voz, world music, interculturalidade é o título do artigo de Simone Luci Pereira, que tematiza a escuta de canções midiáticas como uma forma de consumo cultural. Com destaque para o debate sobre os usos da voz nesse processo, a autora aponta a escuta como agente capaz de possibilitar o conhecimento do Outro.

Em seguida, Herom Vargas debruça-se sobre a década de 1970 para analisar a produção de cantores e compositores identificados com o que chama de "canção experimental". 0 texto Três formas do experimentalismo na MPB da década de 1970 busca discutir aspectos dessas canções no período marcado pela ditadura militar e pela expansão das indústrias midiáticas ligadas ao campo da canção popular.

Outra contribuição internacional para este dossiê é 0 texto de Carolina Spataro, que discute o papel da música na configuração de feminilidades contemporâneas a partir de um estudo de caso com fãs do cantor romântico argentino Ricardo Arjona. 0 artigo intitulado Señora de las cuatro décadas: un estudio sobre el vínculo entre música, mujeres y edad dedica especial ênfase às clivagens etárias e geracionais relacionadas ao vínculo entre canções e feminilidades. A seção de artigos do dossiê se completa com a contribuição de José Cláudio Castanheira, que introduz a temática do "analógico" e do "digital" no artigo Fausto binário: o natural e o artificial em sons analógicos e digitais. Nele, 0 autor discute as relações complexas entre a atual cultura digital e 0 pensamento tecnocientífico contemporâneo, pautado pelo modelo das Tecnologias da Informação (TIs). 
A edição conta ainda com a resenha crítica de Everly Pegoraro do livro Nas bordas e fora do mainstream musical (Estação das Letras e Cores, 2011), organizado por Micael Herschmann. Com o título Música independente no século XXI: percalços, conquistas e desafios, a autora analisa a coletânea que aborda 0 atual momento de transformações da indústria da música, apresentando um panorama analítico das intensas e complexas relações que se estabelecem entre músicos, consumidores/as e mercado.

Finalizando a edição, apresentamos uma entrevista inédita com o pesquisador canadense Will Straw, referência mundial nos estudos sobre música popular. Numa longa conversa com Jeder Janotti Junior, Straw revisita a noção de "cena musical", tornada célebre por ele em texto de 1991 e revisitada pelo próprio autor em artigo de 2006, publicado na E-Compós. Com 0 desenvolvimento das redes sociais dedicadas à música, a noção de cena passou por mudanças, adquirindo novas possibilidades e importância dentro dos estudos de música e comunicação. Nesse ponto, Straw mostra como sua proposta tenta dar conta das relações formadas na circulação global da música popular massiva, sem deixar de lado possíveis encaixes com circulações restritas e referências regionalizadas.

Temos convicção de que a presente edição configura-se como um excelente panorama do universo de pesquisas que circundam a música e som na área de comunicação. As escutas do ruidoso mundo contemporâneo revelam debates e embates sobre pertencimentos, códigos morais, comportamentos compartilhados e experiências individuais e coletivas.

Ouvidos abertos e boa leitura! 